\title{
Vertical stratification of physical, chemical and biological components in two saline lakes Shira and Shunet (South Siberia, Russia)
}

\author{
Andrey G. Degermendzhy • Egor S. Zadereev • Denis Yu. Rogozin • \\ Igor G. Prokopkin · Yuri V. Barkhatov $\cdot$ Alexander P. Tolomeev • \\ Elena B. Khromechek · Jan H. Janse • Wolf M. Mooij • Ramesh D. Gulati
}

Received: 27 June 2010/Accepted: 28 July 2010/Published online: 15 August 2010

(C) The Author(s) 2010. This article is published with open access at Springerlink.com

\begin{abstract}
A feature of meromictic lakes is that several physicochemical and biological gradients affect the vertical distribution of different organisms. The vertical stratification of physical, chemical and biological components in saline, fishless meromictic lakes Shira and Shunet (Siberia, Russia) is quite different mainly because both mean depth and maximum depth of lakes differ as well as their salinity levels differ. The chemocline of the Lake Shira, as in many meromictic lakes, is inhabited by bacterial community consisting of purple sulphur and heterotrophic bacteria. As the depth of the
\end{abstract}

Handling Editor: R.D. Gulati.

A. G. Degermendzhy · E. S. Zadereev $(\bowtie)$.

D. Yu. Rogozin - I. G. Prokopkin - Y. V. Barkhatov • A. P. Tolomeev · E. B. Khromechek

Institute of Biophysics SB RAS, 660036 Krasnoyarsk, Akademgorodok, Russia

e-mail: egor@ibp.ru

E. S. Zadereev · D. Yu. Rogozin

Siberian Federal University, 660041Svobodnyi 79,

Krasnoyarsk, Russia

J. H. Janse

Netherlands Environmental Assessment Agency (PBL), P.O. Box 303, 3720 AH Bilthoven, The Netherlands

W. M. Mooij · R. D. Gulati

Department of Aquatic Ecology, Netherlands Institute of Ecology (NIOO-KNAW), 3631 AC Nieuwersluis,

The Netherlands chemocline is variable, the bacterial community does not attain high densities. The mixolimnion in Lake Shira, which is thermally stratified in summer, also creates different habitat for various species. The distribution of phytoplankton is non-uniform with its biomass peak in the metalimnion. The distribution of zooplankton is also heterogeneous with rotifers and juvenile copepods inhabiting the warmer epilimnion and older copepods found in the cold but oxic hypolimnion. The amphipod Gammarus lacustris which can be assigned to the higher trophic link in the fishless lake's ecosystem, such as Lake Shira, is also distributed non-uniformly, with its peak density generally observed in the thermocline region. The chemocline in Lake Shunet is located at the depth of $5 \mathrm{~m}$, and unlike in Lake Shira, due to a sharp salinity gradient between the mixolimnion and monimolimnion, this depth is very stable. The mixolimnion in Lake Shunet is relatively shallow and the chemocline is inhabited by (1) an extremely dense bacterial community; (2) a population of Cryptomonas sp.; and (3) ciliate community comprising several species. As the mixolimnion of Lake Shunet is not thermally stratified for long period, the phytoplankton and zooplankton populations are not vertically stratified. The gammarids, however, tend to concentrate in a narrow layer located 1-2 $\mathrm{m}$ above the chemocline. We believe that in addition to vertical inhomogeneities of both physicochemical parameters, biological and physical factors also play a role in maintaining these inhomogeneities. We conclude that the 
stratified distributions of the major food web components will have several implications for ecosystem structure and dynamics. Trophic interactions as well as mass and energy flows can be significantly impacted by such heterogeneous distributions. Species spatially separated even by relatively short distances, say a few centimetres will not directly compete. Importantly, we demonstrate that not only bacteria, phytoflagellates and ciliate tend to concentrate in thin layers but also larger-sized species such Gammarus (amphipods) can also under certain environmental conditions have stratified distribution with maxima in relatively thin layer. As the vertical structure of the lake ecosystem is rather complex in such stratified lakes as ours, the strategy of research, including sampling techniques, should consider potentially variable and non-homogeneous distributions.

Keywords Meromictic lakes - Stratification · Sulphur bacteria - Ciliates - Phytoplankton . Gammarus · Mathematical modelling · Cryptomonas · Fishless lakes

\section{Introduction}

Salt lakes have traditionally received less attention from the limnological community. For example, a search for publications using the key word "salt lake" in the Web of Science (1981-2010) revealed is a little over 3,000 publications. This is in no comparison with the number of publications related to sea (search using key world "sea", which delivered over 100,000 publications) and freshwater lake ecosystems (search using "lake not salt" provided 70,000 publications).

Researchers of seas and oceans assign salt lakes to inland water bodies, while traditional fresh water researchers virtually ignore salt lakes from their sphere of interest for no well-known reasons. This attitude was challenged by several pioneers of salt lake research especially Professor W.D. Williams who systematically and unceasingly advocated for scientific values of researches on the salt lakes (e.g. Williams 1993; 2002). We consider that the salt lakes should now receive more attention as new scientific knowledge on such natural water bodies has become available.

The problem of stratification and adaptation of living organisms to physicochemical inhomogeneities of the saline environment is quite a specific one. Notably, it is in the salt lakes that the stratification of the water column is marked most unmistakably and stable. In addition to temperature-density gradients such ecosystems very often have a greater salinityassociated density gradient.

The work on meromictic lakes, i.e. in which the deep recirculation does not always or essentially includes the entire water body, was first summarised by Hutchinson (1957). Recently, Boehrer and Schultze (2008) updated it further, and they give an insight into the current literature and data on permanent stratification of lake. In salt lakes, the bottom layer of water (monimolimnion) very often does not circulate annually due to a strong density difference caused by salinity gradient at the boundary of the mixolimnion and the monimolimnion. As the monimolimnion is excluded from gas exchange for years, it very often becomes anoxic. The mixolimnion and the monimolimnion quite differ in terms of water properties. This change of water properties often happens within a thin water layer, which is called halocline (salinity gradient), chemocline (chemical gradient) or pycnocline (density gradient) (Boehrer and Schultze 2008). The transition zone between the mixolimnion and the monimolimnion is not the only depth where gradients of different factors can be observed in a meromictic lake. If a lake is deep enough, the mixolimnion can be temporarily thermally stratified. Hence, the chemocline does not necessarily coincide with the thermocline. Thus, the water column in deep meromictic lakes can be divided by different gradients into several spatially separated meta-niches. Contrasting environmental conditions that invariably exist in meromictic lakes, affect the vertical distribution of different species. Thus, stratified lakes provide unique opportunities for studying the mechanisms of adaptation of living matter to abruptly changing environmental conditions. It is also very interesting to investigate physiological, ecological and evolutionary consequences of life under salinity and/or anoxic stress.

This Special Issue of Aquatic Ecology (Vol. 44, 3: Gulati, Mooij and Degermendzhy (Eds) (2010) features works related to the problems of stratification in the two meromictic lakes, Lake Shira and Lake Shunet, in southern Siberia. In 2002, we presented detailed data on the structure and functioning of Lake Shira ecosystem in the Special Issue of Aquatic 
Ecology (Gulati and Degermendzhy 2002). The research on these lakes for the past 8 years since the above-mentioned study was conducted has been focused on the patterns and mechanism of stratification of different parameters. This Special Issue (Gulati, Mooij and Degermendzhy (Eds) 2010) presents papers that describe specific mechanism that leads to stratified vertical distribution of physical, chemical properties and biological features of these two lakes. We present our findings in this synthesis paper that essentially summarises the empirical works on the lake. The other synthesis paper (see Mooij et al. 2010) focuses on the lake ecosystem models in general and discusses challenges and opportunities for integrating lake ecosystem modelling approaches. In the present empirical synthesis paper, we attempt to provide a summary of the findings of most other papers in this Special Issue. We do this by comparing the role of physical and biological processes involved in formation of stratification of the components in question.

We start with physicochemical and meteorological parameters which determine the location of the chemocline (Belolipetsky et al. 2010, Genova et al. 2010). We follow it up with the phototrophic sulphur bacteria (PSB), which inhabit the chemocline (Rogozin et al. 2010a). Further, we will discuss the importance of phytoflagellates and ciliates, which also tend to concentrate near the gradients of salinity and water density in our ecosystems (Khromechek et al. 2010). Moving along the trophic chain, we will discuss the vertical distribution of phytoplankton and factors that determine their vertical distribution. For this, we use a complex mathematical model that was developed for meromictic Lake Shira (Prokopkin et al. 2010). The terminal species in the food web of our lakes are amphipods Gammarus lacustris, which tend to occupy pelagic parts of both lakes (Zadereev et al. 2010). It is unusual behaviour for this predominantly benthic amphipod and we discuss which factors promote such a behaviour.

\section{Lakes description}

Lake Shira $\left(54^{\circ} 30^{\prime}\right.$ northern latitude $90^{\circ} 12^{\prime}$ eastern longitude) is a large meromictic water body (length $-9.3 \mathrm{~km}$; width $-5.3 \mathrm{~km}$; water-surface area $-35.9 \mathrm{~km}^{2}$; average depth $-11.2 \mathrm{~m}$; maximum depth
-24 m (2007-2009)) with relatively low concentrations of sulphide (ca. $0.6 \mathrm{mM}$ ) in the monimolimnion. Salinity in summer is about $14-15 \mathrm{~g} \mathrm{l}^{-1}$ in epilimnion and about $18 \mathrm{~g} \mathrm{l}^{-1}$ in monimolimnion, based on data of 2007-2009. A large body of data is now available on this lake's physicochemical and biological properties, vertical distribution of the main plankton groups, primary production, intensity of sulphate reduction, methanogenesis and methane oxidation, species of phytoplankton and zooplankton, etc. (Kopylov et al. 2002; Degermendzhy et al. 2002; Zadereev and Tolomeyev 2007). In terms of physicochemical stratification, the lake is divided into the upper mixolimnion and the lower monimolimnion and the chemocline as an interphase in between these two layers with sharp changes in oxygen, sulphide and redox potential. The position of the chemocline (oxic-anoxic interface) depth varies in depth from 11 to $16 \mathrm{~m}$ depending on the season and year. Based on our present observations and literature data dating back to 1940 s, it can be said that water below the chemocline does not mix. In summer, the water column above the chemocline is also thermally stratified with the thermocline located from about 4 to $8 \mathrm{~m}$. The surface elevation of Lake Shira has noticeably increased over the study period. The lake's salinity decreased because of increase in water volume (Krivosheev and Khasanov 1990). Between the 1920s and 1930s, the lake's level decreased by $7 \mathrm{~m}$, because of a regional decrease in annual precipitation. The salinity reached a maximum of $27 \mathrm{~g}^{-1}$ in 1926 (Krivosheev and Khasanov 1990). We have no available information on the lake's stratification pattern in the 1930s, and it is also unclear whether the lake was meromictic or if it ever turned to a holomictic water.

Lake Shunet (54.25 N; $90.13 \mathrm{E}$ ) is located $8 \mathrm{~km}$ to the southeast of Lake Shira. This lake is elliptical $(1.2 \times 0.4 \mathrm{~km})$ but both much smaller $\left(0.47 \mathrm{~km}^{2}\right)$ and shallower $(6.2 \mathrm{~m})$ than Lake Shira. The ionic composition of the lake water is very similar to that of Lake Shira (Parnachev and Degermendzhy 2002). The salinity of the lake in the mixolimnion (17-20 $\mathrm{g} \mathrm{l}^{-1}$ ) and monimolimnion (up to $66 \mathrm{~g} \mathrm{l}^{-1}$ ) differs markedly (Rogozin et al. 2009). The lake has no surface outflow, but an inflow from a small stream. Due to its sharp inhomogeneity in the water salinity, the lake is strongly meromictic; sulphide concentration in the monimolimnion is about $14 \mathrm{mM}$. The 
surface level of the lake is quite variable; in the beginning of the twentieth century the lake was just $0.5 \mathrm{~m}$ deep and salinity was as high as $380 \mathrm{~g} \mathrm{l}^{-1}$ (Parnachev et al. 2002). The chemical stratification of the lake is quite distinct and differs from that of Lake Shira. The chemocline is thin and located at virtually a constant depth $-5 \mathrm{~m}$ (2004-2009) (Rogozin et al. 2009). In summers, the water column above the chemocline also exhibits a sharp temperature gradient. In calm hot weather, a thermocline may be established at the depth of 3-4 m. However, it is not stable.

\section{Location of the chemocline depth and the stratification of phototrophic sulphur bacteria (PSB)}

Both lakes, Shira and Shunet, remained meromictic during our study period (Rogozin et al. 2009; Rogozin et al. 2010a, b). One-dimensional hydrophysical model seems to be suitable for calculating salinity and temperature profiles in Lake Shira (Genova et al. 2010). Both the meteorological data for different years and model calculations confirmed that the mixolimnion depth depends on the preceding meteorological conditions (Rogozin et al. 2010a; Genova et al. 2010). With snow cover in winter when the chemocline were located deeper, solar irradiance in the chemocline was lower than the minimum intensity of about $0.4 \mu \mathrm{E} \mathrm{m}^{-2} \mathrm{~s}^{-1}$ needed for photosynthetic growth (Van Gemerden et al. 1989) and the concentration of PSB decreased or they were absent (Rogozin et al. 2009). Interestingly, when the overlying snow on ice was absent (March 2007), the light intensity in winter period at the chemocline depth was comparable with that in summer at this depth. Consequently, in winter 2007, Rogozin et al. (2009) discovered the densest "purple layer" for the whole study period (2004-2009).

In Lake Shunet, a strong salinity gradient between the mixolimnion and the monimolimnion persisted throughout the study period. Purple sulphur bacteria (Chromatiaceae) (PSB) peaked in the chemocline zone of the lake (Fig. 1), with a maximum in summer within a depth of $5 \mathrm{~cm}$ at the "sulphide-oxygen" interface: the redox zone (Fig. 2). The bacteriochlorophyll $a$ maximum level of $>10.000 \mu \mathrm{g}^{-1}$, observed in summer is only second on record to that

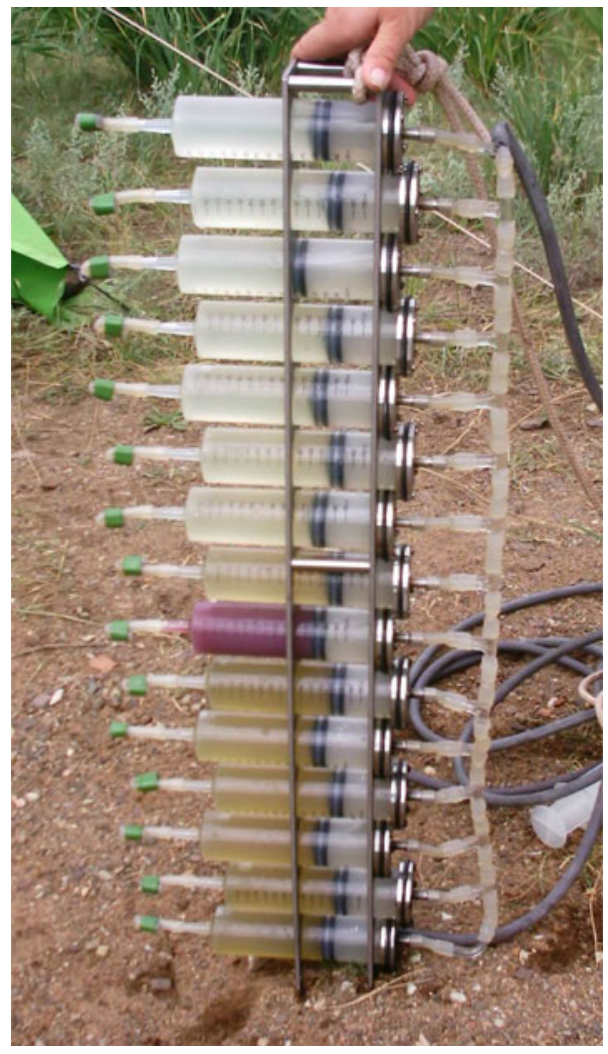

Fig. 1 Multi-syringe thin-layer sampler (Rogozin and Degermendzhy 2008). The photo shows 15 simultaneous, vertical samples taken from Lake Shunet (Siberia, Russia) in August 2004 at 5-cm intervals. The "purple layer" can be easily distinguished (the 9th syringe from the top)

in lake Mahoney Lake (Canada) (Overmann 1997). Typically, in Lake Shunet, the green sulphur bacteria population peaked below the PSB peak. Oxygen, and hydrogen sulphide concentrations and light levels limited these bacterial groups (Degermendzhy et al. 2002).

During the under-ice period, we observed the oxic-anoxic interface to ascend and lie shallower than in summers (Fig. 2), caused apparently by weak anoxic photosynthesis and upward sulphide diffusion through the "purple layer". Only in March 2007 did we observe a simultaneous elevation of the redox zone and PSB (Fig. 2), which could have also been caused by the high photosynthetic activity of PSB because of protracted absence of a snow cover on ice. Thus, the high productivity of PSB in L. Shunet is apparently caused mainly by the presence of both sufficient light and sulphide in the chemocline. In 
Fig. 2 The dynamics of photosynthetic bacterial (PSB) population in Lake Shunet (Siberia, Russia) (Rogozin, unpublished). The contour lines are expressed in $\mu \mathrm{g}$ of bacteriochlorophyll a (Bchl a) $1^{-1}$. Dotted line is the position of the redox zone. $X$-axis represents months and $Y$-axis is the depth (m)

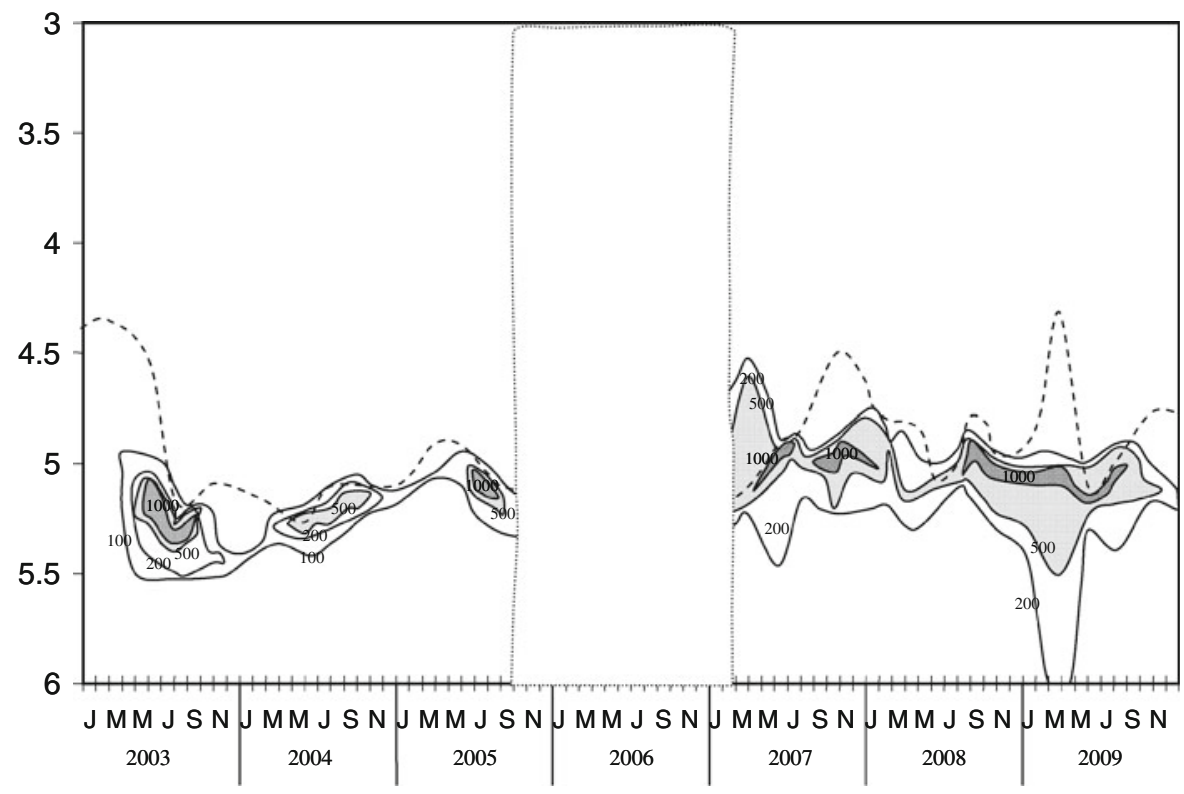

A previous study (Degermendzhy et al. 2002) explains the positioning of the phytoplankton biomass peaks in the water column and reveals light and nutrients as key factors for the shape of vertical distribution of phytoplankton species. The new model of Prokopkin et al. (2010) considers several factors that control phytoplankton dynamics: irradiance, water temperature and nutrients, growth, mortality, respiration, and sedimentation of organic matter. The food web aspects included in the model are consumption of phytoplankton by zooplankton and the amphipod Gammarus lacustris.

Model calculations show that the filter-feeding calanoid Arctodiaptomus salinus considerably affects the vertical distribution of phytoplankton (Fig. 3b). Cyanobacteria dominate during summer in the absence of zooplankton in model calculations (Fig. 3b). This, however, contradicts the field data (Gaevsky et al. 2002). Prokopkin et al. (2010) also show that because of constant, diurnal fluctuations in the under-water light intensity, there is no fixed depth in the water column where light conditions are optimal for phytoplankton growth. Thus, light hardly seems to affect sinking or shift of dominant phytoplankton (Prokopkin et al. 2010). Sedimentation rates of phytoplankton seem to be important in determining phytoplankton biomass peaks in water column, i.e. the biomass is concentrated in the subsurface water layers if sedimentation is absent (Fig. 3c).
In L. Shira, the green alga Dictyosphaerium peaked in July at ca. $8 \mathrm{~m}$ and in August at 10-12 m (Gaevsky et al. 2002). Prokopkin et al. (2010) confirmed the layering patterns of this green alga and Cyanobacteria based on an ecosystem model of Lake Shira (Fig. 3a). 
Biomass, mg /1

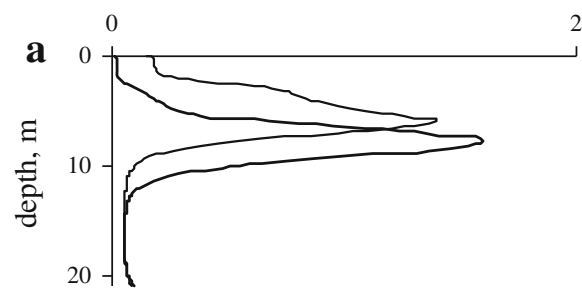

Biomass, mg /1

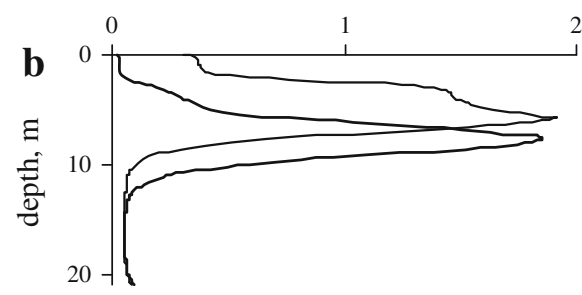

Biomass, mg /1

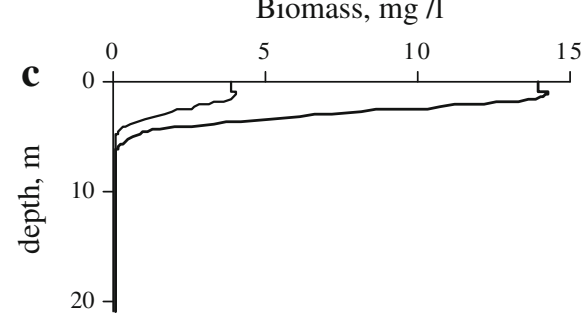

Fig. 3 Model calculations (Prokopkin et al. 2010) of the vertical distribution of green alga (thick line) and Cyanobacteria (thin line) biomass. Left panels show the results for July 15, the right panels show the results for August 06.

Model sensitivity analysis (Prokopkin et al. 2010) supports the importance of sedimentation in the positioning of maximum biomass of green alga Dictyosphaerium. The key role of sedimentation for the vertical distribution of phytoplankton species, as revealed by model of Prokopkin et al. (2010), needs laboratory verification.

\section{Stratification of phytoflagellates and ciliates}

It seems that in Lake Shunet both Cryptomonas spp. and their common ciliate predator genera (Oligotrichida, Scuticociliatida, Hypotrichida and Prostomatida) (Khromechek et al. 2010) are adapted to poor light conditions, anoxia and hydrogen sulphide in the lake. The population of Cryptomonas sp. always remained at the oxic-anoxic interface, where it reached $3,000-35,000$ cells $\mathrm{ml}^{-1}$ in $5-10 \mathrm{~cm}$
Biomass, mg /l

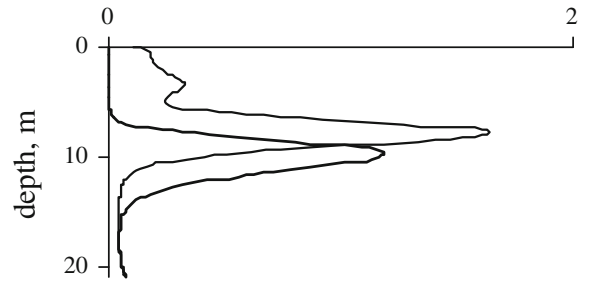

Biomass, mg /1

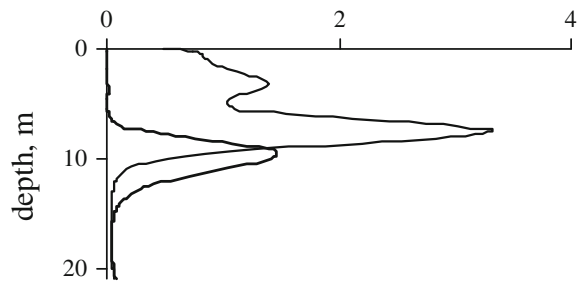

Biomass, mg /1

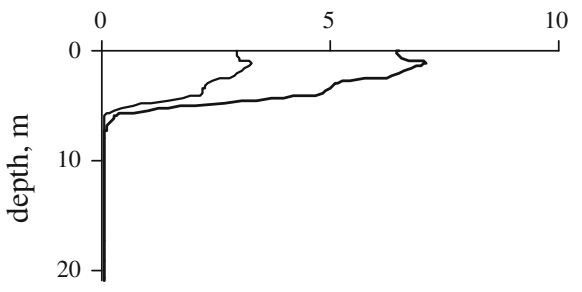

a Calculations under standard conditions; b Results obtained in the absence of trophic pressure exerted by zooplankton; c Calculations in the absence of phytoplankton sedimentation

above or at the chemocline. The ciliate abundance (50-400 cells $\mathrm{ml}^{-1}$ ) in the chemocline was an order lower; the community in the pelagic zone clearly preferred the $10-35 \mathrm{~cm}$ layer of the chemocline, above or in the layer of PSB where the $\mathrm{H}_{2} \mathrm{~S}$ level varied from 0 to $5 \mathrm{mg} \mathrm{l}^{-1}$. The community does not seem to migrate, but with a diel maximum somewhat higher than that of Cryptomonas spp. Large populations of these flagellates in the chemocline is perhaps related to the co-occurrence of dense population of PSB (Rogozin et al. 2005, 2009, 2010a, b). A flow of nutrients from the lake bottom is needed to maintain such densities of bacteria and the flagellates. Moreover, in Lake Shunet, large crustacean filter-feeding zooplankters such as Daphnia are conspicuous by their absence: the main grazers, instead, are the calanoid Arctodiaptomus salinus and the rotifers Brachionus plicatilis and Hexarthra oxiuris. The consumption of Cryptomonas 
by A.salinus is supported by direct feeding experiments and presence of fatty acid trophic markers (Tolomeev et al. 2010). However, since these grazers cannot stay for a long time in the anaerobic water, this allows Cryptomonas to recoup and maintain their population in this zone.

Thus, our data confirm earlier reports (Gasol et al. 1992; Massana et al. 1994; Gervais 1998) that stratified water bodies often contain large populations of cryptomonads in the chemocline region. Secondly, ciliate populations are the main grazers of algae in the monimolimnion of our meromictic lakes (PedrósAlió et al. 1995).

\section{Gammarus lacustris: its adaptations to living in pelagic zones of meromictic lakes}

Gammarus is traditionally considered a littoral-benthic species, and its influence on the pelagic system is relatively not well known (MacNeil et al. 1997). Wilhelm and Schindler (1999) and Kelly et al. (2002) have shown that Gammarus can live in a pelagic zone and play part in the trophic chain here. Although there are no fish or other predators in the pelagic zone of both our study lakes, the lake bottom in both the cases not a suitable habitat for benthic species such as Gammarus sp. mainly because monimolimnion is anoxic. To answer the question if presence of Gammarus in the pelagic part is consistent with its habitat requirements, especially depth preference, we monitored the vertical distribution of this amphipod in the centre of the lakes employing video surveillance system during summer stratification in 2005 , 2007 and 2008 (Zadereev et al. 2010). Gammarus appears to be distributed non-homogenously during summer stratification, with a stable peak in the metalimnion (Fig. 4) with maximal population abundance in the thermocline within the pelagic zone. The population peak of G. lacustris in the metalimnion can be explained by the absence of predators in the pelagic zone, high oxygen concentration, low temperature, increased seston concentration, and higher water density in the metalimnion.

Gammarus densities using video system and vertical plankton net hauls were comparable and similar to that of dominant zooplankton grazers. Their population areal biomass in the pelagic zone was $15 \mathrm{~g} \mathrm{~m}^{-2}$ versus $20 \mathrm{~g} \mathrm{~m}^{-2}$ for Arctodiaptomus

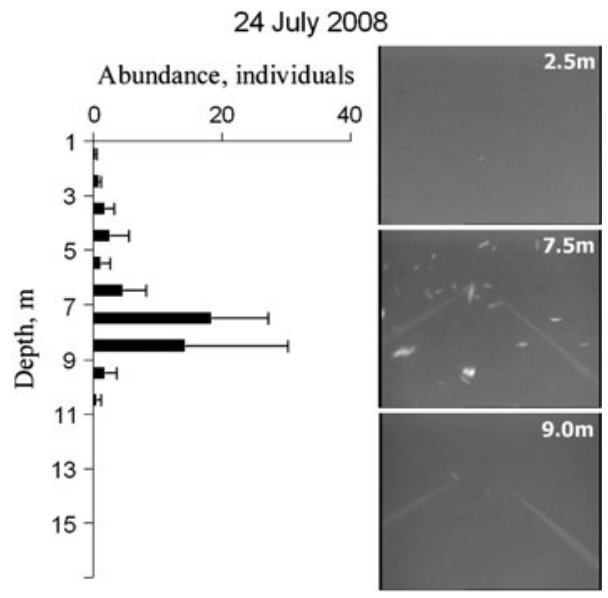

Fig. 4 Typical vertical distribution of Gammarus lacustris in the pelagic zone of Lake Shira (Siberia, Russia) during summer stratification. To the right are examples of the still-frame images obtained using the submersible video surveillance system

salinus, and also comparable with the maximum areal biomass of Brachionus plicatilis $\left(15 \mathrm{~g} \mathrm{~m}^{-2}\right)$ in July (Zadereev and Tolomeyev 2007).

We determined the role of Gammarus in the pelagic trophic chain using its diet and growth rates. Although Gammarus is known as a predator in pelagic systems (Wilhelm and Schindler 1999), we do not know if that true also for L. Shira. Gladyshev et al. (2000) study on the fatty acids in the stomach contents of Gammarus from Lake Shira shows that the animals probably feed on freshly sedimented seston. We also know that the food of Gammarus from near the shore and the lake's central part does not significantly differ (Dr. E. Zadereev, unpublished data), which implies a diet overlap in the animals food menu in the two lake parts. Moreover, Tolomeyev et al. (2006), based on a survival study of Gammarus on the lake's seston in a 20-day mesocosm experiment, conclude that Gammarus can survive for long periods on in situ concentrations of lake seston particles. Generalising thus, the biomass of G. lacustris in the pelagic zone of Lake Shira during summer stratification is comparable with the biomass of the dominating species of zooplankton; and that the lake seston can serve as the main food source for this amphipod. Nevertheless, the effect of G. lacustris on the lake's ecosystem structure and dynamics remains underexplored. We do not know to what extent Gammarus contributes to the lake's food 
chain. Fish being absent, is Gammarus a top predator in the lake's ecosystem (Zadereev and Gubanov 2002) or is it a mere competitor with pelagic zooplankton for its seston food? Such questions need to be addressed in future research on the trophic relationships in the lake.

We modelled the effect of Gammarus on the pelagic seston in Lake Shira by using a complex mathematical lake model by Prokopkin et al. (2010). Even though the data on ecology, physiology and life cycle of Gammarus in Lake Shira are incomplete, we make some simple assumptions to test whether Gammarus can impact the pelagic seston concentrations. The growth rate of amphipods in the model is limited only by the water temperature (Prokopkin et al. 2010). Using data of Tolomeyev et al. (2006) and Gladyshev et al. (2000), we can assume that Gammarus feeds on all three major components of the lake seston, namely, detritus, green algae and Cyanobacteria (Prokopkin et al. 2010), in proportion to their relative concentrations in the lake. The modelled vertical distribution of Gammarus has a biomass peak at the metalimnion, which agrees with field data of Zadereev et al. (2010). Comparing the vertical distribution of seston carbon in the pelagic part of Lake Shira for 15 days, with and without Gammarus in pelagic waters, it appears that Gammarus is able to control the seston carbon (Fig. 5) in lake water. Thus, the presence of Gammarus in open water seems to be an intriguing and an important feature of meromictic lakes, e.g. lakes Shira and Shunet, which lack fish due probably to high salinity. However, a more specific research directed to trophic dynamics of Gammarus in order to examine the role that this "predominantly" benthic animal plays in the lake's ecosystem, is needed to quantify its importance in energy flow.

\section{Discussion}

We depict in Fig. 6 a scheme of the vertical stratification of physical, chemical and biological components in two saline lakes Shira and Shunet. Notably, patterns of physico-chemical stratification of the two lakes are quite different mainly because both mean depth and maximum depth of lakes differ as well as their salinity levels differ too. Of these 2 lakes, Lake Shira is deeper and less saline has a

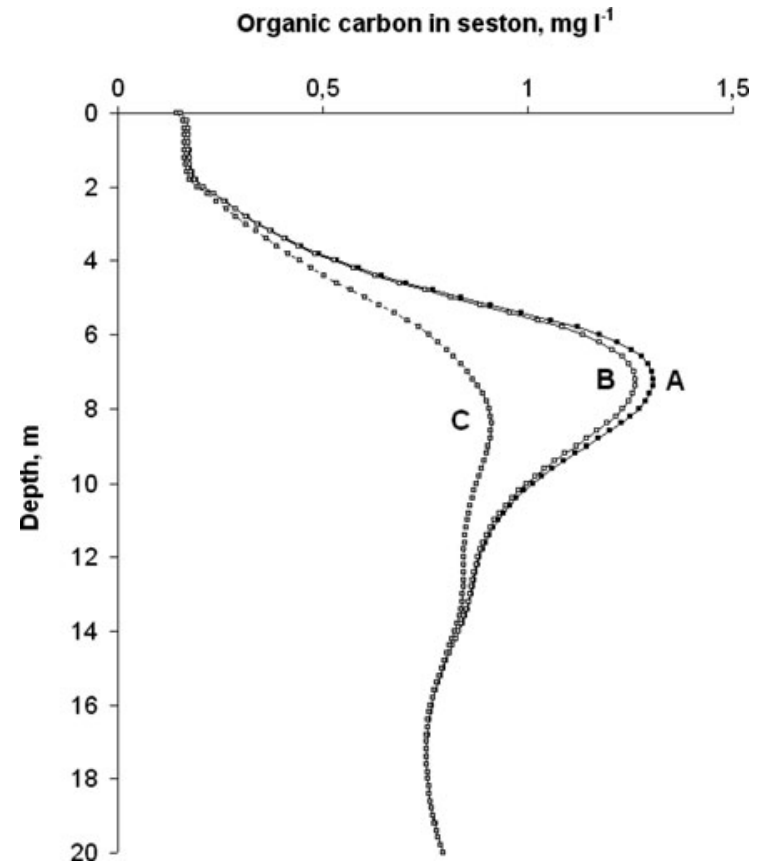

Fig. 5 The modelled vertical distribution of organic carbon in seston in the pelagic zone of Lake Shira (Siberia, Russia) without $(A)$ and with $(B, C)$ Gammarus lacustris in the water column. $B$ the total biomass of $G$. lacustris is $3.8 \mathrm{~g} \mathrm{~m}^{-2}$, which is averaged biomass observed in the pelagic zone during summer stratification in July; $C$ the total biomass of $G$. lacustris is $38 \mathrm{~g} \mathrm{~m}^{-2}$, which is biomass occasionally observed in the pelagic zone during summer stratification in July (Dr. A. Yemelianova unpublished)

chemocline with variable depth. Depending on the weather conditions, the chemocline can sink to deeper waters $(16 \mathrm{~m})$ or ascend to shallower depth (11 m). However, we did not observe mixing of entire water column, nor is it reported in literature. Considering that the mixolimnion of Lake Shira is relatively deep and that it is surrounded by hills, the mixolimnion is also thermally stratified during the summer period. The thermocline is formed at the depth of 3-4 m, usually in the middle of June. In summer, the surface waters become warmer and the thermocline sinks downwards to $8-9 \mathrm{~m}$ depth by the end of August. Thus, in the summer time, the three layers are an upper warm epilimnion, the metalimnion (where the temperature drop is $>1{ }^{\circ} \mathrm{C}$ per $\mathrm{m}$ ) and an oxic hypolimnion, which is separated from the anoxic monimolimnion by the chemocline.

This type of physico-chemical stratification in L. Shira leads to stratification of biological components. The chemocline of the lake, as in many meromictic 


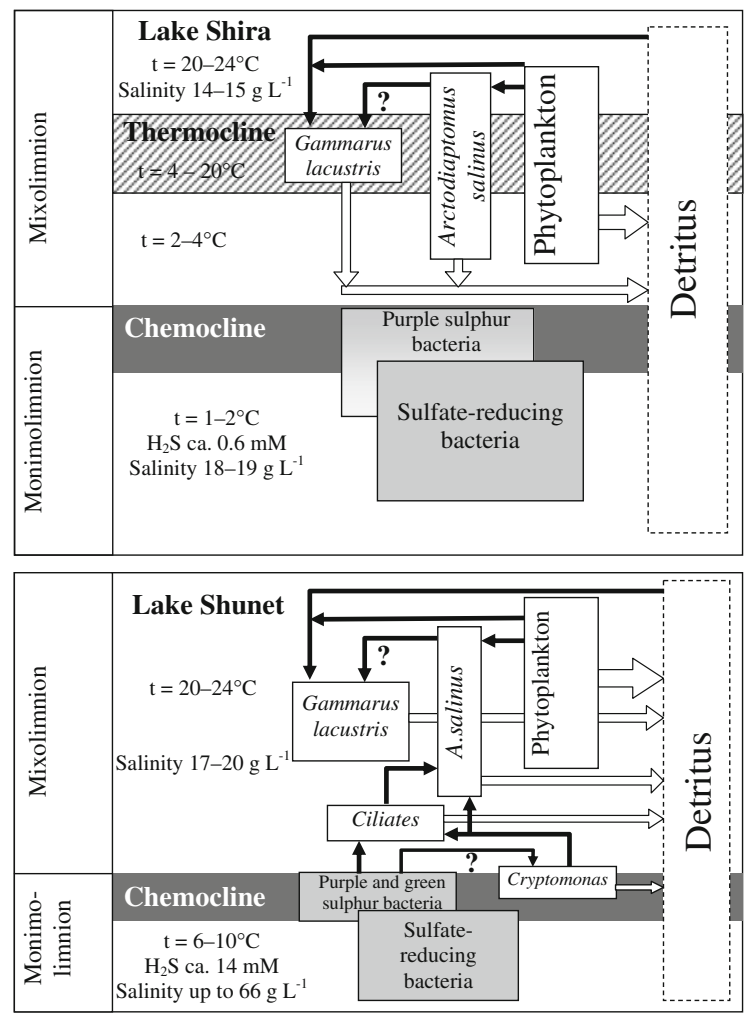

Fig. 6 Scheme of vertical stratification of physical, chemical and biological components in saline lakes Shira and Shunet (South Siberia, Russia) in summer. The size of compartments and different zones are not drawn to scale the abundance of species or the depth of the specific zone. The position of compartments demonstrates the location of the given species in the water column. Exact depths, physical and chemical values and concentrations of biological components are presented in Fig. 7 as well as described in the text in the Lakes Description section. Solid arrows demonstrate trophic interactions. Question marks (?) are related to trophic interactions that are not yet confirmed but are commensurate with literature data

lakes, is inhabited by bacterial community consisting from purple sulphur and heterotrophic bacteria. However, because the depth of the chemocline is variable, the bacterial community does not reach high densities. When the chemocline shifts downwards or upwards the bacterial community is "diluted". The thermally stratified in summer, the mixolimnion also creates different habitats for various species. The distribution of phytoplankton is non-uniform with the peak of biomass in the metalimnion. The distribution of zooplankton is also non-uniform with rotifers and juvenile copepods in warm epilimnion and older copepods in the cold oxic hypolimnion (Zadereev and
Tolomeyev 2007). Zooplankton comprised of the calanoid Arctodiaptomus sp. and rotifers feed mostly on phytoplankton. Moreover, we consider the bacterial community in the chemocline as a not-essential part of the trophic chain in the mixolimnion. The amphipods which can be assigned to the higher trophic link in the lake's ecosystem are also distributed non-uniformly, with their peak densities generally associated with the thermocline. They stay in pelagic region, feed on seston and probably also on zooplankton. However, studies of fatty acid composition of Gammarus reveal no traces of any zooplankton prey in its gut.

The chemocline in Lake Shunet is located at $5 \mathrm{~m}$, and unlike for Lake Shira, this depth varies only narrowly, $\pm 20 \mathrm{~cm}$, which is certainly due to a very sharp salinity gradient between mixolimnion (17-20 $\mathrm{g} \mathrm{l}^{-1}$ ) and monimolimnion (up to $66 \mathrm{~g} \mathrm{l}^{-1}$ ). As Lake Shunet has much lower mean depth and the mixolimnion in Lake Shunet is not deep enough, like in Lake Shira, its thermal stratification in summer is not stable. Because the depth of the chemocline in Lake Shunet is stable and the mixolimnion is relatively shallow, the chemocline is inhabited by the extremely dense bacterial community, a population of Cryptomonas sp. and ciliate community comprising several species. In contrast, in Lake Shira the densities of both Cryptomonas sp. and ciliates are low and more evenly distributed in the water column. As the mixolimnion of Lake Shunet is not thermally stratified for a long period, the vertical distribution of phytoplankton and zooplankton too is not vertically stratified. However, gammarids tend to concentrate in narrow layer located 1-2 $\mathrm{m}$ above the chemocline. The trophic interactions in Lake Shunet appear to partially differ from those in Lake Shira, where bacterial community is much denser and Cryptomonas sp. and several ciliate species inhabit the chemocline. Both ciliates and zooplankton feed on bacterial community in the chemocline. Both the ciliates and calanoid, A.salinus, also feed on Cryptomonas sp. which are most probably mixotrophic in the chemocline and consume bacteria.

Despite our several studies (e.g. Degermendzhy et al. 2002; Gaevsky et al. 2002; Rogozin et al. 2005; Tolomeyev et al. 2006; Zadereev and Tolomeyev 2007) on the vertical structure of L. Shira and L. Shunet, our knowledge on the food web interactions and mass and energy flows is rather scanty. We still do not have a good grasp of the impact of microbial 
loop and bacterial and ciliates communities in the chemocline on the macrobial food web and energy budget in the mixolimnion. Moreover, we still do not quite understand the effect of Gammarus population (Zadereev et al. 2010) on the pelagic food web. The studies of trophic interactions are the subject for futures studies. Also, a missing link in our research, as in many research studies on lakes, is the interactions between littoral and pelagial lake zones. Because gammarids are quite abundant in lake's littoral as well as its pelagial and perform horizontal migrations between these two regions (Yemelyanova et al. 2002), the work on Gammarus needs to be integrated more coherently with lakes' other food chain studies.

Both L. Shira and L. Shunet, with their complex stratified vertical structures appear to be very sensitive to external changes especially to climate change. First, meromixis is sensitive to lake water level, which depends on the input-output balance of water, depending mainly on annual precipitation and evaporation. The water levels of our study lakes are quite variable, as evident from great changes witnessed over last 150 years. The increase in water level though increased input of rain water or anthropogenic run-off leads to a decrease in salinity and consequently to less stable stratification. Thus, with the consistent rise of water level, meromixis can be eventually destroyed. The water level of both lakes increased during last one decade. We have, however, no information if this increase was due to climate change or just a local, temporal trend. The effect of climate changes on the local conditions is difficult to assess. However, what we at this stage can model and predict is the effect of lake water level increases on the changes in stability of the stratification of water column. Such an estimate will enable us to monitor and account for possible changes in lake properties in future.

The stratification of physicochemical and biological parameters in the ecosystems of lakes Shira and Shunet, and the mathematical analysis shows that there are no simple and uniform mechanisms to explain how stratification is formed (Fig. 7). The depth of the chemocline in L. Shira is determined by meteorological conditions (air temperature and wind) rather than by microbial activity. Also, in Lake Shira, where stratification is less stable, the development of the bacterial community is primarily limited by the fluctuating depth of the chemocline On the other hand, in L. Shunet, where the salinity gradient is more marked and the stratification more stable, also the biological bacterial activity can determine the depth of the chemocline.

The phytoplankton is non-uniformly distributed with depth in L. Shira. The vertical distribution of many phytoplankton species is determined together by both physico-chemical and biological processes. For example, sensitivity analysis of the mathematical model of the Lake Shira ecosystem (Prokopkin et al. 2010) shows that the depth of the biomass maximum of green algae is strongly affected by maximum sedimentation rate. The vertical distribution of green algae is also influenced by trophic pressure of zooplankton (Fig. 4b) and others factors (Fig. 7).

Cryptomonas sp. and several ciliate species show distinct preference for a certain depth; they establish dense community in the chemocline of Lake Shunet. Phytoflagellates (Cryptomonas sp.) may inhabit the stable and permanent chemocline because of the availability there of nutrients and organic substrate. We know that many genera of phytoflagellates can switch to mixotrophic feeding in fresh and marine aquatic ecosystems (Porter 1988; Sanders 1991). Another possible mechanism of formation of deep phytoflagellate maximum is the absence of large predators, too sensitive to withstand high content of $\mathrm{H}_{2} \mathrm{~S}$. Ciliate density maximum above the chemocline may be due to both the high content of nutrients and the high tolerance of ciliates to $\mathrm{H}_{2} \mathrm{~S}$ (Fig. 7).

Presence of Gammarus lacustris, traditionally regarded as a benthic-littoral species in the lake's pelagic area, raises certain questions as to how these animals adapt to such a habitat. G. lacustris not only inhabits the pelagic zone, but also forms a strongly marked non-homogeneous distribution with its maximum in the thermocline zone. Again, the role of hydrophysical and biological factors in this distribution is not well understood. On the one hand, the average depth where the population occurs is consistently associated with the thermocline (Zadereev et al. 2010). The thermocline of these 2 saline lakes is the depth zone where the amphipods are maximally buoyant. Also in the thermocline zone, the conditions are optimal for growth and development of the amphipods, i.e. low temperatures, high oxygen concentrations and high seston concentrations (Fig. 7). 


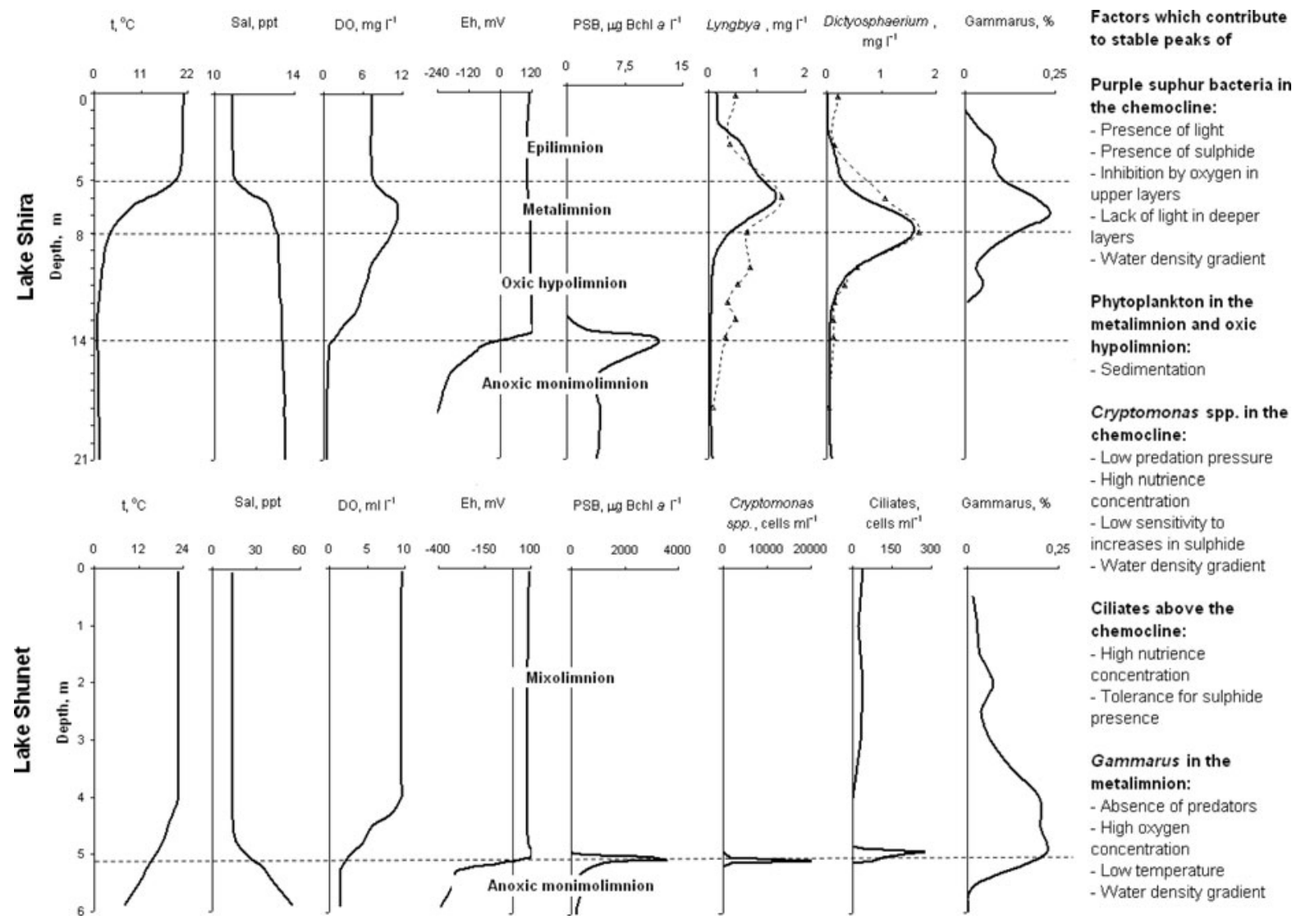

Fig. 7 Typical mid-summer stratification of the water column in lakes Shira and Shunet (Siberia, Russia) and vertical distributions of several species related to physicochemical gradients. Physicochemical parameters (temperature (t), salinity (Sal), concentration of dissolved oxygen (DO), redox potential (Eh)) are measured by YSI 6600 data sonde (YSI Corp., USA). Data on the purple sulphur bacteria (PSB) estimated as the concentration of bacteriochlorophyll $a$ (Bchl a) are calculated on the basis of the collated data on the summer vertical distributions (Rogozin unpublished); Lyngbia and Dictyosphaerium spp. lines with dots indicate previously

\section{Conclusion}

Salinity is crucial factor: it both supports the meromictic conditions and controls the species richness and food web structure in saline Siberian lakes. Life under saline and low oxygen conditions leads to stress and certain unusual food web structures.

1. The food chain in both the lakes is clearly truncated. The fish and other predators are absent. The amphipod Gammarus lacustris, being a typical littoral/benthic species, is the highest trophic link in both the lakes. It seems, published data (Gaevsky et al. 2002), thick lines are calculations performed using a complex mathematical model developed to simulate the seasonal development of the ecosystem of Lake Shira (Prokopkin et al. 2010). Relative abundance in percentage of Gammarus lacustris (Gammarus) in the water column is calculated on the basis of the data collated for several years on the vertical distributions of Gammarus in July (Zadereev et al. 2010). Data on Cryptomonas spp. and ciliates are obtained on 27 July 2005 from the same samples (Khromechek et al. 2010)

however, that Gammarus competes with zooplankton species for seston, rather than that it controls the food web from the top. The most obvious explanation for such a simplified food web structure is elevated salinity and persistent meromictic conditions. In addition, high concentration of $\mathrm{H}_{2} \mathrm{~S}$ in bottom layers is also among reasons which do not allow fish population to be established in the pelagic of lakes. The study lakes are relatively young, having evolved in the post-glacial period. They are thus also young for adaptation of species to specific meromictic 
habitat. Having been recently established in the middle of the Siberian sub-continent, and with very high salt content and water chemistry that is very different from that of the sea water, the lakes have little chances to be inhabited by either freshwater or sea species.

Without fish and large-bodies grazers (daphnids), the top-down cascade is also absent. Growth rates of calanoid copepoda which dominate the lakes' zooplankton have slower rates than for Cladocera and are also known to be less efficient in controlling phytoplankton. The question remains whether the decrease in salinity that has been recently noted will lead to the introduction of fish species, and cladoceran zooplankton, with substantial alteration of food web structure.

2. The spatial heterogeneities of biological components play important role in ecosystem structuring and functioning. The vertical structures of the stratified lake ecosystem are rather complex and most probably are under investigated.

In our lakes, the diversity of pelagic zooplankton and phytoplankton is not very high and we can easily observe how species are segregated in space. Even though the paradox of Hutchinson 'the paradox of the plankton' is now considered more as a general paradigm than an enigma for limnologists, the mechanisms which promote species richness in lakes are still topic for intense research. In the inhomogeneous environment, species vertically segregated even by short distances (centimetres) will not directly compete. Thus, our systems are a good example of how the paradox of Hutchinson can be resolved.

The chemocline of our both lakes, as in other meromictic lakes, is inhabited by thin layers (about $5 \mathrm{~cm}$ ) of photosynthetic purple sulphur and heterotrophic bacteria. In Lake Shunet, the chemocline is also inhabited by a population of Cryptomonas sp. and ciliate community comprising at least 4 species. In Lake Shira, the thermal stratification of the mixolimnion in summer creates different habitats for various species. The peak of phytoplankton biomass is detected in the metalimnion. Rotifers and juvenile copepods of the calanoid Arctodiaptomus sp. reside in the warm epilimnion but adult calanoids prefer the cold oxic hypolimnion. The amphipod Gammarus lacustris is surprisingly abundant and distributed non-uniformly in the pelagic region of both lakes. Their peak densities are generally associated with the thermocline. Thus, the stratified distributions seem to be typical for species ranging in size and complexity, i.e. from bacteria to amphipods.

Lastly, trophic interactions and mass and energy flow will be significantly impacted by such stratified distribution of major biotic components. If certain species are concentrated at a specific depth, they can have major trophic effects at this depth, but virtually none at the adjacent depths.

Acknowledgments The work was supported by Project N2004 0.47.011.2004.030 (the Russian Foundation for Basic Research and the Netherlands Organization for Scientific Research). Also it was partially supported by grant No. PG07-002-1 of the CRDF and the Ministry of Education and Sciences of Russian Federation; by the Russian Foundation for Basic Research (RFBR) grants No. 08-04-00928, 09-04-01114a, 09-05-00915-a, by RFBR and Krasnoyarsk region Science Foundation Grant no. 09-04-98042-r_sibir_a; by the Siberian Branch of Russian Academy of Sciences, Integrative Project No. 95 and joint Taiwan-Siberian Project No. 149; by the Russian Academy of Sciences, Program "Biodiversity", Project No. 23.15.

Open Access This article is distributed under the terms of the Creative Commons Attribution Noncommercial License which permits any noncommercial use, distribution, and reproduction in any medium, provided the original author(s) and source are credited.

\section{References}

Belolipetsky PV, Belolipetskii VM, Genova SN, Mooij WM (2010) Numerical modeling of vertical stratification of Lake Shira in summer. Aquat Ecol. doi: 10.1007/s10452010-9330-z

Boehrer B, Schultze M (2008) Stratification of lakes. Rev Geophys 46:1-27

Degermendzhy AG, Belolipetsky VM, Zotina TA, Gulati RD (2002) Formation of the vertical heterogeneity in the Lake Shira ecosystem: the biological mechanisms and mathematical model. Aquat Ecol 36(2):271-297

Gaevsky NA, Zotina TA, Gorbaneva TB (2002) Vertical structure and photosynthetic activity of Lake Shira phytoplankton. Aquat Ecol 36:165-178

Gasol JM, Guerrero R, Pedrós-Alió C (1992) Spatial and temporal dynamics of a metalimnetic Cryptomonas peak. J Plankton Res 14:1565-1579

Genova SN, Belolipetskii VM, Rogozin DY, Degermendzhy AG, Mooij WM (2010) A one-dimensional model of vertical stratification of Lake Shira focussed on winter 
conditions and ice cover. Aquat Ecol. doi: 10.1007/ s10452-010-9327-7

Gervais F (1998) Ecology of cryptophytes coexisting near a freshwater chemocline. Freshwater Biol 39:61-78

Gladyshev MI, Emelianova AY, Kalachova GS, Zotina TA, Gaevsky NA, Zhilenkov MD (2000) Gut content analysis of Gammarus lacustris from a Siberian lake using biochemical and biophysical methods. Hydrobiologia 431: 155-163

Hutchinson GE (1957) A treatise on Limnology, vol. 1. Geography, Physics and Chemistry. Wiley, New York

Kelly DW, Dick JTA, Montgomery WI (2002) The functional role of Gammarus (Crustacea, Amphipoda): shredders, predators, or both? Hydrobiologia 485:199-203

Khromechek EB, Barkhatov YV, Rogozin DY (2010) Densities and distribution of flagellates and ciliates in the chemocline of saline, meromictic Lake Shunet (Siberia, Russia). Aquat Ecol. doi: 10.1007/s10452-010-9332-x

Kopylov AI, Kosolapov DB, Romanenko AV, Degermendzhy AG (2002) Structure of planktonic microbial food web in a brackish stratified Siberian lake. Aquat Ecol 36: 179-204

Krivosheev AS, Khasanov AP (1990) Therapeutic lakes of Krasnoyarsk region. Publishing House, Krasnoyarsk (In Russian)

Lunina ON, Bryantseva IA, Akimov VN, Rusanov II, Barinova ES, Lysenko AM, Rogozin DY, Pimenov NV (2007) Anoxygenic phototrophic bacteria community of Lake Shira (Khakassia). Microbiology 76:469

MacNeil C, Dick JT, Elwood RW (1997) The trophic ecology of freshwater Gammarus spp. (Crustacea: Amphipoda): Problems and perspectives concerning the functional feeding group concept. Biol Rev Camb Philos Soc 72:349-364

Massana R, Gasol JM, Jürgens K, Pedrós-Alió C (1994) Impact of Daphnia pulex on a metalimnetic microbial community. J Plankton Res 16:1379-1399

Mooij WM, Trolle D, Jeppesen E, Arhonditsis G, Belolipetsky PV, Chitamwebwa DBR, Degermendzhy AG, DeAngelis DL, De Senerpont Domis LN, Downing AS, Elliott JA, Fragoso Jr CR, Gaedke U, Genova SN, Gulati RD, Håkanson L, Hamilton DP, Hipsey MR, 't Hoen J, Hülsmann S, Los FJ, Makler-Pick V, Petzoldt T, Prokopkin IG, Rinke K, Schep SA, Tominaga K, Van Dam AA, Van Nes EH, Wells SA, Janse, JH (2010) Challenges and opportunities for integrating lake ecosystem modelling approaches. Aquat Ecol doi:10.1007/s10452-0109339-3

Overmann J (1997) Mahoney Lake: a case study of the ecological significance of phototrophic sulfur bacteria. In: Jones (ed) Adv Microbial Ecol 15:251-288

Parnachev VP, Degermendzhy AG (2002) Geographical, geological and hydrochemical distribution of saline lakes in Khakasia, Southern Siberia. Aquat Ecol 36:107-122

Parnachev VP, Vishnevezky II, Makarenko NA, Petrov AI, Kopilova JG, Smetanina OV, Karnachuk OV, Turov YP, Klopotova NG, Djabarova NK, Banks D, Berezovsky AJ (2002) Natural waters of Shira district in Khakass Republic/Edited by VP Parnachev. Tomsk State University, Tomsk, p183 (In Russian)
Pedrós-Alió C, Massana R, Latasa M, García-Cantizano J, Gasol JM (1995) Predation by ciliates on a metalimnetic Cryptomonas population: feeding rates, impact and effects of vertical migration. J Plankton Res 17:2131-2154

Porter KG (1988) Phagotrophic phytoflagellates in microbial food webs. Hydrobiologia 159:89-97

Prokopkin IG, Mooij WM, Janse JH, Degermendzhy AG (2010) A general one-dimensional vertical ecosystem model of Lake Shira (Russia, Khakasia): description, parametrization and analysis. Aquat Ecol. doi: 10.1007/s10452010-9326-8

Rogozin DY, Degermendzhy AG (2008) Hydraulically-operated thin-layer sampler for sampling heterogeneous water columns. J Siberian Fed Univ 1:111-117

Rogozin DY, Pimenov NV, Kosolapov DB, Chan'kovskaya YV, Degermendzhy AG (2005) Thin-layer vertical distributions of purple sulfur bacteria in chemocline zones of meromictic lakes Shira and Shunet (Khakassia). Dokl Biol Sci 400:54-56

Rogozin DY, Zykov VV, Chernetsky MY, Degermendzhy AG, Gulati RD (2009) Effect of winter conditions on distributions of anoxic phototrophic bacteria in two meromictic lakes in Siberia, Russia. Aquat Ecol 43:661-672

Rogozin DY, Genova SN, Gulati RD, Degermendzhy AG (2010a) Some generalisations based on stratification and vertical mixing in meromictic Lake Shira, Russia, in the period 2002-2009. Aquat Ecol. doi:10.1007/s10452010-9328-6

Rogozin DY, Trusova MY, Khromechek EB, Degermendzhy AG (2010b) Microbial community of chemocline of meromictic lake Shunet (Khakassia, Russia) during summer stratification. Microbiology 79:253-261

Sanders RW (1991) Trophic strategies among heterotrophic flagellates. In: Patterson DJ, Larsen J (eds) The biology of heterotrophic flagellates. Clarendon Press, Oxford, pp 21-38

Tolomeev AP, Sushchik NN, Gulati RD, Makhutova ON, Kalacheva GS, Zotina TA (2010) Feeding spectra of Arctodiaptomus salinus (Calanoida, Copepoda) using fatty acid trophic markers in seston food in two salt lakes in South Siberia (Khakasia, Russia). Aquat Ecol. doi: 10.1007/s10452-010-9331-y

Tolomeyev AP, Zadereev ES, Degermendzhy AG (2006) Fine stratified distribution of Gammarus lacustris Sars (Crustacea: Amphipoda) in the pelagic zone of the meromictic lake Shira (Khakassia, Russia). Dokl Biochem Biophys 411:346-348

Van Gemerden H, Tughan CS, de Wit R, Gerbert RA (1989) Laminated microbial ecosystems on sheltered beaches in Scapa flow, Orkney Islands. FEMS Microbiol Ecol 62:87-102

Wilhelm FM, Schindler DW (1999) Effects of Gammarus lacustris (Crustacea: Amphipoda) on plankton community structure in an alpine lake Canadian. J Fish Aquat Sci 56:1401-1408

Williams WD (1993) Conservation of salt lakes. Hydrobiologia 267:291-306

Williams WD (2002) Environmental threats to salt lakes and the likely status of inland saline ecosystems in 2025. Environ Conserv 29:154-167 
Yemelyanova AY, Temerova TA, Degermendzhy AG (2002) Distribution of Gammarus lacustris Sars (Amphipoda, Gammaridae) in Lake Shira (Khakasia, Siberia) and laboratory study of its growth characteristics. Aquat Ecol 36:245-256

Zadereev YS, Gubanov MV (2002) The effect of chemicals released by Gammarus lacustris on the depth distribution of Arctodiaptomus salinus in laboratory conditions. Aquat Ecol 36:257-260
Zadereev YS, Tolomeyev AP (2007) The vertical distribution of zooplankton in brackish meromictic lake with deepwater chlorophyll maximum. Hydrobiologia 576: 69-82

Zadereev ES, Tolomeyev AP, Drobotov AV, Emeliyanova AYu, Gubanov MV (2010) The vertical distribution and abundance of Gammarus lacustris in the pelagic zone of the meromictic lakes Shira and Shunet (Khakassia, Russia). Aquat Ecol. doi: 10.1007/s10452-010-9329-5 